\title{
Mapping of the environmental contamination of Toxoplasma gondii by georeferencing isolates from chickens in an endemic area in Southeast Rio de Janeiro State, Brazil
}

\author{
Luciana Casartelli-Alves, ${ }^{1}$ Maria Regina Reis Amendoeira, ${ }^{2}$ Viviane Cardoso Boechat, ${ }^{1}$ \\ Luiz Cláudio Ferreira, ${ }^{1}$ João Carlos Araujo Carreira, ${ }^{2}$ José Leonardo Nicolau, ${ }^{2}$ \\ Eloiza Paula de Freitas Trindade, ${ }^{2}$ Julia Novaes de Barros Peixoto, ${ }^{3}$ \\ Mônica de Avelar Figueiredo Mafra Magalhães, ${ }^{3}$ Raquel de Vasconcellos Carvalhaes de \\ Oliveira, ${ }^{1}$ Tânia Maria Pacheco Schubach, ${ }^{1}$ Rodrigo Caldas Menezes ${ }^{1}$ \\ ${ }^{1}$ Evandro Chagas National Institute of Infectious Diseases, Oswaldo Cruz Foundation, Rio \\ de Janeiro; ${ }^{2}$ Oswaldo Cruz Institute, Oswaldo Cruz Foundation, Rio de Janeiro; \\ ${ }^{3}$ Institute of Communication and Scientific and Technological Information in Health, \\ Oswaldo Cruz Foundation, Rio de Janeiro, Brazil
}

Correspondence: Rodrigo Caldas Menezes, National Institute of Infectiology Evandro Chagas, Oswaldo Cruz Foundation, Av. Brasil 4365, Manguinhos, 21040360 Rio de Janeiro, Brazil.

Tel: +55.21 .3865 .9536 - Fax: +55.21 .3865 .9553$

E-mail: rodrigo.menezes@ipec.fiocruz.br

Key words: T. gondii; Chickens; Environmental contamination; Kernel density estimator; Brazil.

Ethical statement: the 51 owners of the farms studied were interviewed using an assessment instrument for epidemiological investigation after signing an informed consent form. The study was approved by the Ethics Committee on Animal Use of the Oswaldo Cruz Foundation (Permit No. L012/09). The informed consent form and questionnaire applied to the owners were approved by the Ethics Committee on Human Research, Evandro Chagas Clinical Research Institute, FIOCRUZ (Protocol No. 0034.0.009.000.09)

Acknowledgements: we thank Maíra C.H. Cavalcanti for technical support, Rodrigo Méxas from 0swaldo Cruz Institute, Brazil, for processing the figures, and Dr. Fátima Madeira and the team of Laboratory for Leishmaniasis Surveillance (Evandro Chagas National Institute of Infectious Diseases) for their collaboration with the study.

Funding: the study was supported by Fundação Carlos Chagas Filho de Amparo à Pesquisa do Estado do Rio de Janeiro (FAPERJ) (Grants: APQ1 E26/110.937/2009, APQ1 E-26/111.977/2012, TCT E-26/102.303/2011, and JCNE E-26/102.247/2013) and by Conselho Nacional de Desenvolvimento Científico e Tecnológico (CNPq) (Grant MCT/CNPq 10/2010 -AT- NM). TMPS has a research productivity fellowship from $\mathrm{CNPq}$.

Received for publication: 12 January 2015.

Revision received: 12 March 2015.

Accepted for publication: 15 March 2015.

(C) Copyright L. Casartelli-Alves et al., 2015

Licensee PAGEPress, Italy

Geospatial Health 2015; 10:311

doi:10.4081/gh.2015.311

\section{Abstract}

The environmental contamination of Toxoplasma gondii in an endemic area in Brazil was mapped by georeferencing isolates from chickens in farms in the Southeast of the state of Rio de Janeiro. Tissue samples obtained from 153 adult chickens were analyzed by the mouse bioassay for $T$. gondii infection. These animals were reared free-range on 51 farms in the municipalities of Rio Bonito and Maricá. The ArcGIS kernel density estimator based on the frequency of $T$. gondii-positive chickens was used to map the environmental contamination with this parasite. A questionnaire was applied to obtain data on the presence and management of cats and the type of water consumed. Of the farms studied, $64.7 \%$ were found to be located in areas of low to medium presence of $T$. gondii, $27.5 \%$ in areas with a high or very high contamination level and $7.8 \%$ in non-contaminated areas. Additionally, $70.6 \%$ kept cats, $66.7 \%$ were near water sources and $45.0 \%$ were in or near dense vegetation. Humans used untreated water for drinking on $41.2 \%$ of the farms, while all animals were given untreated water. The intensity of environmental T. gondii contamination was significantly higher on farms situated at a distance $>500 \mathrm{~m}$ from water sources $(\mathrm{P}=0.007)$ and near $(\leq 500 \mathrm{~m})$ dense vegetation $(\mathrm{P}=0.003)$. Taken together, the results indicate a high probability of $T$. gondii infection of humans and animals living on the farms studied. The kernel density estimator obtained based on the frequency of chickens testing positive for T. gondii in the mouse bioassay was useful to map environmental contamination with this parasite.

\section{Introduction}

Toxoplasmosis is a worldwide zoonosis caused by the protozoan Toxoplasma gondii, which affects mammals and birds (Millar et al., 2012). Free-range chickens have been used worldwide as indicators of environmental contamination with T. gondii oocysts (Dubey et al., 2008). These animals eat food directly off the ground and the probability of infection through ingestion of $T$. gondii oocysts is therefore high (Dubey, 2010). In addition, the direct detection of oocysts in soil by laboratory techniques is difficult and only $1 \%$ of cats excretes oocysts at any time (Beltrame et al., 2012). The importance of free-range chick- 
ens for the epidemiology of toxoplasmosis is also related to the fact that their meat is a source of infection for humans and other animals (Hill and Dubey, 2013).

Remote sensing and geographic information systems (GIS) are useful for the analysis of environmental factors related to the spatial distribution of infectious diseases (Meneguzzi et al., 2009; Silva et al., 2011; Djokič et al., 2014), and the risk maps emanating from this kind of investigation can be used to implement measures for the control and prevention of such diseases (Meneguzzi et al., 2009). However, the few existing studies on georeferencing of $T$. gondii infection are based on the results of serological tests in goats (Djokič et al., 2014), in cats (Afonso et al., 2013) and in otters (Chadwick et al., 2013). In this respect, mapping environmental contamination based on the isolation of $T$. gondii from free-range chickens in an endemic area may indicate sites, where the possibility of infection of humans and animals with this parasite is high. The objective of the present study was to apply georeferencing of $T$. gondii isolates from free-range chickens to map sites of environmental contamination with this parasite in an endemic area in Brazil.

\section{Materials and methods}

\section{Study area}

The municipalities of Maricá and Rio Bonito, located in the SouthEastern part of the state of Rio de Janeiro, Brazil (Figure 1), were chosen for this study because they are considered to be endemic for toxoplasmosis (Luciano et al., 2011; Casartelli-Alves et al., 2012). According to the Statistical Yearbook of the State of Rio de Janeiro (CEPERJ), Maricá had a population of 127,461 inhabitants in 2010 census and comprises an area of $362 \mathrm{~km}^{2}$ (CEPERJ, 2012). The municipal human development index (MHDI) of Maricá is 0.765 according to the United Nations Development Programme (UNDP, 2013). The main economic activities are livestock farming, agriculture, small industries, mineral exploration, construction, fishing and tourism (CEPERJ, 2012; UNDP, 2013). There is a large lagoon complex (Maricá-Guarapina) nearby that communicates with the Atlantic Ocean. The municipality is located $4 \mathrm{~m}$ above the mean sea level (MSL) and has a tropical climate with a mean annual temperature of $23.2^{\circ} \mathrm{C}$ and an annual precipitation of $1100 \mathrm{~mm}$ (CEPERJ, 2012). The land is partly covered by rainforest or restinga, the coastal tropical and subtropical broadleaf forest vegetation typical for Eastern Brazil.

Rio Bonito had a population of 55,551 inhabitants in 2010 census, it comprises an area of $456 \mathrm{~km}^{2}$ (CEPERJ, 2012), and its MHDI is 0.710 (UNDP, 2013). The main economic activities are fruit crops and livestock farming (CEPERJ, 2012; UNDP, 2013). The municipality is located $40 \mathrm{~m}$ above MSL, has a typical rainforest vegetation and a humid tropical climate with a mean annual temperature of $26^{\circ} \mathrm{C}$ and annual precipitation of 1500 to $2000 \mathrm{~mm}$ (CEPERJ, 2012).

\section{Study sample}

A total of 153 adult chickens (Gallus gallus domesticus) reared freerange on 51 farms between April 2009 and July 2011 were studied. Forty-one chickens were from 13 farms in Rio Bonito and 112 were from 38 farms in Maricá. Three animals per farm were evaluated. The chickens were euthanized and subjected to necropsy to collect samples of brain, heart and thigh muscle for the mouse bioassay.

\section{Mouse bioassay}

The mouse bioassay was used since it is considered a reference standard method for the diagnosis of T. gondii in chickens (Dubey, 2010), and also because it permits to evaluate the viability of the parasite in chicken tissues. The assay was performed using a previously described protocol (Casartelli-Alves et al., 2014). Briefly, a pool of $20 \mathrm{~g}$ of tissue samples collected from each chicken was triturated, homogenized, digested with an acid pepsin solution and inoculated into five mice. The bioassay was deemed positive when $T$. gondii was observed in tissues or peritoneal exudate of the mice, or when anti-T. gondii antibody titers were detected in the serum of the mice by indirect hemagglutination test.

\section{Geospatial analysis}

The waypoints of the 51 farms from which the chickens of this study were obtained were marked with a Geko 301 Global Positioning System (GPS) instrument from Garmin (Olathe, KS, USA), which permits the calculation of latitude and longitude with an accuracy of $10 \mathrm{~m}$. Hydrographic data were extracted from the land cover map of the Foundation Center for Information and Data of the State of Rio de Janeiro (CIDE) for the year 2001 (CIDE, 2001). Data on soil use were obtained by visual interpretation of a colour composition of images with bands 3-4-5 of Landsat 5 TM (http://www.dgi.inpe.br/ siteDgi/ATUS_LandSat.php) with a 30 -m spatial resolution, provided by the National Institute for Space Research (INPE) (http://www.dgi. inpe.br/Suporte/files/Cameras-LANDSAT57_PT.php). After elaboration of a database containing all waypoints, the distance (in meters) of the farms from areas of dense vegetation and water sources (rivers and lagoons) was calculated using the ArcGis, version 9.1 (ESRI, Redlands, CA, USA). The properties were defined as being near areas of dense vegetation and water sources when located at a distance $\leq 500 \mathrm{~m}$ from these areas, and as distant when located at a distance $>500 \mathrm{~m}$.

A GIS using the waypoints of each farm and the kernel density estimator with Gaussian function and a smooth kernel of 100-m radius (Silva et al., 2011) was applied to spatially identify areas and their intensity of environmental contamination with $T$. gondii. The parameter used for elaboration of the maps using the kernel density estimator (kernel maps) was the frequency of $T$. gondii-positive chickens in the mouse bioassay per farm studied. This frequency was classified into

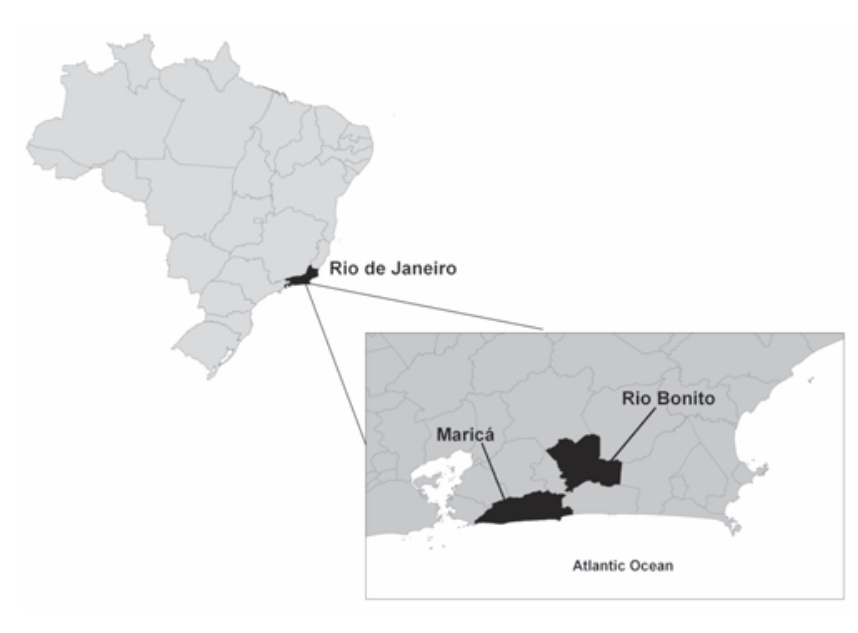

Figure 1. The study area consisted of farms in the municipalities of Rio Bonito and Maricá in the state of Rio de Janeiro, Brazil. 
the following ranges: high when the frequency was $100 \%$; medium when $67 \%$; low when $33 \%$ and negative when $0 \%$. On the basis of these frequencies, the intensity of environmental contamination on the kernel map of each municipality was classified into the following density ranges expressed by color: very high (red color), high (dark orange color), medium (light orange color), low (yellow color) and negative (no color). The number of farms located in the different areas of environmental contamination and land cover was counted on the maps resulting from this operation. Areas in the map showing dense or low vegetation were considered to be rural.

\section{Questionnaire-generated data}

Additional data were collected by questionnaires asking the following questions: presence of cat(s); type of food fed to the cat(s); other rodent control methods if applied; type of water consumed by humans and animals; and method for disposal of chicken carcasses and viscera.

\section{Statistical analysis}

The selection of the farms was non-random. The exploratory analysis was based on comparisons of the frequencies of intensity of environmental $T$. gondii contamination and variables that included the questionnaire information, farm location (urban or rural), proximity of the farm to water sources (rivers/lagoons) and proximity to dense vegetation. Statistical analysis was done using the Statistical Package for the Social Sciences (version 16.0) for Windows. Fisher's exact test was used to determine statistically significant associations (exact $\mathrm{P}<0.05$ ) between the intensity of environmental $T$. gondii contamination and the variables described above.

\section{Results}

Sixty-three (41.2\%) of the 153 chickens studied were positive for $T$. gondii in the mouse bioassay. According to the kernel map (Figure 2), $64.7 \%(n=33)$ of the 51 farms studied were located in areas of low to medium environmental presence of T. gondii, $27.5 \%(\mathrm{n}=14)$ in areas
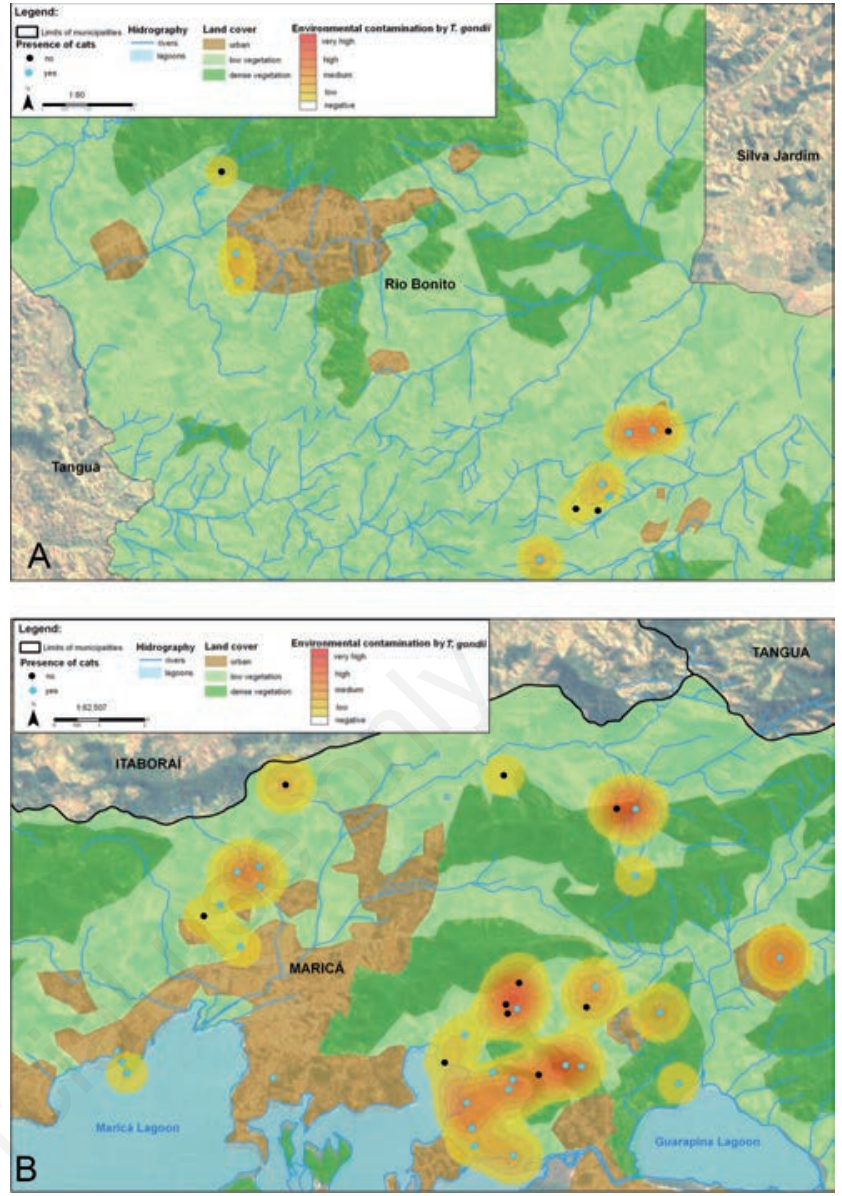

Figure 2. Kernel map showing the intensity of $T$. gondii contamination, hydrographic characteristics, soil use, and the presence of cats between April 2009 and July 2011 on farms in the municipalities of Rio Bonito (A) and Maricá (B) in the South-Eastern of the state of Rio de Janeiro, Brazil. Negative=non-contaminated area.

Table 1. Farm characteristics and Toxoplasma gondii contamination in areas with farms in the South-Eastern part of the state of Rio de Janeiro, Brazil from April 2009 to July 2011.

\begin{tabular}{|c|c|c|c|c|c|}
\hline \multirow{2}{*}{ Farm characteristics } & & \multicolumn{4}{|c|}{ Intensity of environmental contamination ${ }^{\circ}$} \\
\hline & & $\begin{array}{l}\text { Non-contaminated } \\
\qquad(\mathrm{n}=4)\end{array}$ & $\begin{array}{l}\text { Low to medium } \\
(\mathrm{n}=33)\end{array}$ & $\begin{array}{l}\text { High or very high } \\
\qquad(\mathrm{n}=14)\end{array}$ & $\begin{array}{l}\text { Total } \\
(\mathrm{n}=51)\end{array}$ \\
\hline Presence of cats & $\begin{array}{l}\text { Yes } \\
\text { No }\end{array}$ & $\begin{array}{c}4(7.8) \\
0(0)\end{array}$ & $\begin{array}{l}23(45.1) \\
10(19.6)\end{array}$ & $\begin{array}{l}9(17.6) \\
5(9.8)\end{array}$ & $\begin{array}{l}36(70.6) \\
15(29.4)\end{array}$ \\
\hline Type of area & $\begin{array}{l}\text { Urban } \\
\text { Rural }\end{array}$ & $\begin{array}{l}2(3.9) \\
2(3.9)\end{array}$ & $\begin{array}{c}3(5.9) \\
30(58.8)\end{array}$ & $\begin{array}{c}0(0) \\
14(27.5)\end{array}$ & $\begin{array}{c}5(9.8) \\
46 \quad(90.2)\end{array}$ \\
\hline Distance from water (m) & $1-500$ & $4(7.8)$ & $25(49.0)$ & $5(9.8)$ & $34 \quad(66.6)$ \\
\hline & $>500$ & $0(0)$ & $8(15.7)$ & $9(17.7)$ & $17 \quad(33.4)$ \\
\hline Distance from dense vegetation (m) & $\begin{array}{l}0 \# \\
1-500 \\
>500\end{array}$ & $\begin{array}{l}1(2.0) \\
1(2.0) \\
2(3.9)\end{array}$ & $\begin{array}{c}7(13.7) \\
3(5.9) \\
23(45.1)\end{array}$ & $\begin{array}{c}4(7.8) \\
7(13.7) \\
3(5.9)\end{array}$ & $\begin{array}{ll}12 & (23.5) \\
11 & (21.6) \\
28 & (54.9)\end{array}$ \\
\hline
\end{tabular}

Values in brackets represent percentages. ${ }^{\circ}$ In areas where farms were located according to the kernel density estimator. In view of the small counts obtained for some of the intensity categories of environmental contamination, non-contaminated and low to medium categories were pooled for the statistical analysis. \#Situated within vegetation. 
with a high, or very high, level of contamination and $7.8 \%(n=4)$ in areas without $T$. gondii. Table 1 shows the frequency of the presence or absence of cats, type of area, and distance from water sources and dense vegetation. The intensity of environmental $T$. gondii contamination was significantly higher on farms located $>500 \mathrm{~m}$ from water sources (64.3\% for high/very high intensity vs $21.6 \%$ for negative/low to medium intensity, $\mathrm{P}=0.007)$ and near dense vegetation $(78.6 \%$ for high/very high intensity $v s 32.4 \%$ for negative/low to medium intensity, $\mathrm{P}=0.003)$.

In Maricá, $65.8 \%(\mathrm{n}=25)$ of the farms were located in areas of low vegetation, $26.3 \%(n=10)$ in areas of dense vegetation, and $7.9 \%(n=3)$ in the urban area. In Rio Bonito, $69.2 \%(n=9)$ of the farms were located in areas of low vegetation, $15.4 \%(n=2)$ in areas of dense vegetation, and $15.4 \%(n=2)$ in the urban area.

Cats were present on $69.2 \%(\mathrm{n}=9)$ of the 13 farms located in Rio Bonito and on $71.1 \%(\mathrm{n}=27)$ of the 38 farms located in Maricá. In Rio Bonito, $84.6 \%(n=11)$ of the 13 farms were located in areas of environmental contamination with $T$. gondii; cats were present on $63.6 \%(n=7)$ of these farms. In Maricá, $94.7 \%(n=36)$ of the 38 farms were located in areas of environmental contamination with $T$. gondii and cats were present on $69.4 \%(n=25)$ of them. The cats were fed commercial ration on $58.3 \%(\mathrm{n}=21)$ of the 36 farms where they were present and the type of food was unknown for $41.7 \%(n=15)$ of these farms because the animals were neighbourhood cats. On the 21 farms where the cats were fed commercial ration, these animals were also fed raw or undercooked pork or beef on $19.0 \%(n=4)$ and raw or undercooked chicken meat or viscera on $9.5 \%(n=2)$. The viscera and carcasses of dead chicken were buried on $82.4 \%(\mathrm{n}=42)$ of the farms, discarded in the trash on $5.9 \%$ $(n=3)$, disposed of in the environment on $7.8 \%(n=4)$, and burned on $3.9 \%(n=2)$. Chemical products and traps were the only method for the control of rodents on $58.8 \%(n=30)$ of the farms; $25.5 \%(n=13)$ of the farms used only cats for this purpose, and both methods were used on $15.7 \%(n=8)$ of the farms.

With respect to the water consumed by chickens on the 51 farms, the water was obtained from a well on $80.4 \%(n=41)$ of the farms, from a river or spring on $15.7 \%(n=8)$, and from both on $3.9 \%(n=2)$. Chickens and other farm animals were given untreated water (unfiltered and not boiled) on all farms. Analysis of the type of water consumed by humans revealed origin from a well on $74.5 \%(\mathrm{n}=38)$ of the farms, from a river or spring on $5.9 \%(\mathrm{n}=3)$ and from commercial bottled water on $19.6 \%$ $(n=10)$. Humans used untreated water (unfiltered and not boiled) for drinking on $41.2 \%(n=21)$ of the farms and treated water (filtered) for drinking on $58.8 \%(\mathrm{n}=30)$.

There was no statistically significant association between the intensity of environmental $T$. gondii contamination and the variables location of the farm in an urban or rural area; presence of cats; type of food fed to the cats; other rodent control methods if applied; type of water consumed by humans and animals; and method for disposal of chicken carcasses and viscera.

\section{Discussion}

A high frequency of farms located in areas of environmental contamination with $T$. gondii was observed in the two municipalities studied. This environmental contamination was demonstrated by the high percentage of chickens testing positive in the mouse bioassay, thus carrying viable parasites in their tissues. A high frequency of environmental contamination has also been demonstrated in other regions of Brazil by serological surveys and isolation of $T$. gondii from free-range chickens
(Oliveira et al., 2009; Dubey et al., 2012). In the state of Rio de Janeiro, higher environmental contamination than that found here has been observed in the municipality of Campos dos Goytacazes, where the percentage of isolation of $T$. gondii from free-range chickens was $70.9 \%$ by the mouse bioassay (Silva et al., 2003). Since human contact with $T$. gondii oocysts present in soil is greater in rural than in urban areas (Afonso et al., 2008), the findings of the present study suggest the possibility of infection of the population from the area studied with $T$. gondii, especially in the rural area.

The high frequency of cats on the farms studied and the fact that a high intensity of environmental contamination was only observed in areas where cats were present suggest a role of these animals in soil contamination in the municipalities studied. These results agree with other authors (Millar et al., 2012), who correlated the presence of cats with a higher risk of $T$. gondii infection in free-range chickens. Freerange chickens are an important source of infection for cats which, when ingesting chicken meat containing $T$. gondii tissue cysts, can excrete millions of oocysts (Dubey et al., 2002). The high environmental contamination observed in some places can be due to meat or viscera of slaughtered chickens which cats are fed to (or made available by inadequate disposal) in raw or undercooked form. However, this hypothesis was not confirmed statistically, probably because of the low number of farms where these feeding habits occurred. Cats are often used for control of rodents, and this is the explanation for the high frequency of cats on the farms studied, a fact also reported by other authors investigating T. gondii infection on chicken farms (Millar et al., 2012). However, the correlation between the presence of cats and the intensity of environmental $T$. gondii contamination observed by kernel density estimatior was not confirmed by Fisher's exact test. The lack of a statistically significant association by Fisher's exact test may be due to the fact that this test does not consider the individual aspects of each area indicated by the kernel, which is the most appropriate method for this analysis. Additionally, four farms where cats were present were located in non-contaminated areas and there were 15 farms without cats located in areas with environmental contamination (Table 1). The lack of an association between the presence of cats and environmental contamination has been reported for pig and sheep farms (Luciano et al., 2011; Ortega-Pacheco et al., 2013). Furthermore, a study investigating defecation sites of cats in an urban area concluded that the areas most contaminated with oocysts were not necessarily those with the largest number of cats (Afonso et al., 2008). One possible explanation for the absence of environmental contamination in some areas where cats were present is that these particular animals did not eliminate oocysts in their feces. The observation of areas of contamination, where no cats were present, suggests the possibility of dispersion of parasite oocysts by other factors such as rain, proximity to water sources, wind, or the presence of mechanical vectors.

Although the intensity of environmental $T$. gondii contamination was significantly higher on farms distant from water sources, more than half the farms in areas with environmental contamination by $T$. gondii were located near water sources. This finding suggests the possibility of water contamination at these sites with parasite oocysts carried by rainwater from the soil of the farms. Outbreaks of human toxoplasmosis in Brazil related to the consumption of water contaminated with $T$. gondii 0ocysts have been described in Rio de Janeiro (Bahia-Oliveira et al., 2003), Paraná (Moura et al., 2006) and Ceará (Heukelbach et al., 2007). The use of untreated water for drinking by humans and farm animals is frequent in farms from the state of Rio de Janeiro, as observed by Millar et al. (2012) and in the present study. These data therefore suggest the possibility of infection of the population and animals of these areas through the consumption of water contaminated 
with T. gondii 0ocysts. In the present study, the finding that the intensity of environmental $T$. gondii contamination was significantly higher on farms located near dense Atlantic rainforest vegetation suggests that wild cats may contribute to environmental contamination in the region by eliminating oocysts in their feces. The Atlantic rainforest in the state of Rio de Janeiro, including the municipalities of Maricá and Rio Bonito, is the habitat of four wild cat species that have been shown to be able to excrete $T$. gondii oocysts in faeces. These species are Herpailurus yagouaroundi (jaguarundi), Leopardus pardalis (ocelot), Panthera onca (jaguar), and Puma concolor (cougar) (Jewell et al., 1972; Patton et al., 1986; Rocha et al., 2004; Elmore et al., 2010). AntiT. gondii antibodies have also been detected in omnivorous birds from the Atlantic Rainforest and the frequency of infection was higher among those eating food off the ground (Gennari et al., 2014). These results indicate a possible transmission by sporulated oocysts present in the wild, a fact that may have also occurred in the present study.

\section{Conclusions}

The high frequency of farms located in areas of environmental contamination with $T$. gondii, the frequent presence of cats, the proximity of water sources, and the high consumption of untreated water observed on these farms suggest a high probability of infection of humans and animals with this parasite. The kernel density estimator obtained based on the frequency of chickens testing positive for $T$. gondii in the mouse bioassay was a suitable tool to map environmental contamination with this parasite, providing useful information for the control and prevention of toxoplasmosis.

\section{References}

Afonso E, Germain E, Poulle ML, Ruette S, Devillard S, Say L, Villena I, Aubert D, Gilot-Fromont E, 2013. Environmental determinants of spatial and temporal variations in the transmission of Toxoplasma gondii in its definitive hosts. Int J Parasitol Parasites Wildl 2:27885.

Afonso E, Lemoine M, Poulle ML, Ravat MC, Romand S, Thulliez P, Villena I, Aubert D, Rabilloud M, Riche B, Gilot-Fromont E, 2008. Spatial distribution of soil contamination by Toxoplasma gondii in relation to cat defecation behaviour in an urban area. Int $\mathrm{J}$ Parasitol 38:1017-23.

Bahia-Oliveira LMG, Jones JL, Azevedo-Silva J, Alves CCF, Oréfice F, Addiss DG, 2003. Highly endemic, waterborne toxoplasmosis in north Rio de Janeiro state, Brazil. Emerg Infect Dis 9:55-62.

Beltrame MA, Pena HF, Ton NC, Lino AJ, Gennari SM, Dubey JP, Pereira FE, 2012. Seroprevalence and isolation of Toxoplasma gondii from free-range chickens from Espírito Santo state, southeastern Brazil. Vet Parasitol 188:225-30.

Casartelli-Alves L, Boechat VC, Macedo-Couto R, Ferreira LC, Nicolau JL, Neves LB, Millar PR,Vicente RT, Oliveira RVC, Muniz AG, Bonna ICF, Amendoeira MRR, Silva RC, Langoni H, Schubach TMP, Menezes RC, 2014. Sensitivity and specificity of serological tests, histopathology and immunohistochemistry for detection of Toxoplasma gondii infection in domestic chickens. Vet Parasitol 204:346-51.

Casartelli-Alves L, Ferreira LC, Vicente RT, Millar PR, Oliveira RVC, Amendoeira MRR, Schubach TMP, Menezes RC, 2012. Prevalence of Toxoplasma gondii infection in free-range chickens reared in Rio Bonito, Rio de Janeiro. Arq Bras Med Vet Zootec 64:1398-401.

CEPERJ, 2012. Centro estadual de estatísticas, pesquisas e formação de servidores públicos do Rio de Janeiro Statistical. Available from: http://www.ceperj.rj.gov.br/ceep/Anuario2012/index.html

Chadwick EA, Cable J, Chinchen A, Francis J, Guy E, Kean EF, Paul SC, Perkins SE, Sherrard-Smith E, Wilkinson C, Forman DW, 2013. Seroprevalence of Toxoplasma gondii in the Eurasian otter (Lutra lutra) in England and Wales. Parasite Vector 6:75.

CIDE, 2001. Centro de informações e dados do Rio de Janeiro. Anuário Estatístico do Estado do Rio de Janeiro, Governo do Estado do Rio de Janeiro ed., Brazil.

Djoki V, Klun I, Musella V, Rinaldi L, Cringoli G, Sotirak S, Djurkovi Djakovi 0, 2014. Spatial epidemiology of Toxoplasma gondii infection in goats in Serbia. Geospat Health 8:479-88.

Dubey JP, 2010. Toxoplasma gondii infections in chickens (Gallus gallus domesticus): prevalence, clinical disease, diagnosis and public health significance. Zoonoses Public Hlth 57:60-73.

Dubey JP, Graham DH, Blackston CR, Lehmann T, Gennari SM, Ragozo AM, Nishi SM, Shen SK, Kwok OC, Hill DE, Thulliez P, 2002. Biological and genetic characterization of Toxoplasma gondii isolates from chickens (Gallus domesticus) from São Paulo, Brazil: unexpected findings. Int J Parasitol 32:99-105.

Dubey JP, Lago EG, Gennari SM, Su C, Jones JL, 2012. Toxoplasmosis in humans and animals in Brazil: high prevalence, high burden of disease, and epidemiology. Parasitology 139:1375-424.

Dubey JP, Velmurugan GV, Chockalingan A, Pena HF, de Oliveira LN, Leifer CA, Gennari SM, Bahia-Oliveira LM, Su C, 2008. Genetic diversity of Toxoplasma gondii isolates from chickens from Brazil. Vet Parasitol 157:299-305.

Elmore SA, Jones JL, Conrad PA, Patton S, Lindsay DS, Dubey JP, 2010. Toxoplasma gondii: epidemiology, feline clinical aspects, and prevention. Trends Parasitol 26:190-6.

Gennari SM, Ogrzewalska M, Soares HS, Saraiva DG, Pinter A, Labruna MB, Dubey JP, 2014. Occurrence of Toxoplasma gondii antibodies in birds from the Atlantic Forest, state of São Paulo, Brazil. Vet Parasitol 200:193-7.

Heukelbach J, Meyer-Cirkel V, Moura RCS, Gomide M, Queiroz JAN, Saweljew P, Liesenfeld 0, 2007. Waterborne toxoplasmosis, Northeastern Brazil. Emerg Infect Dis 13:287-9.

Hill DE, Dubey JP, 2013. Toxoplasma gondii prevalence in farm animals in the United States. Int J Parasitol 43:107-13.

Jewell ML, Frenkel JK, Johnson KM, Reed V, Ruiz A, 1972. Development of Toxoplasma oocysts in neotropical felidae. Am J Trop Med Hyg 21:512-7.

Luciano DM, Menezes RC, Ferreira LC, Nicolau JL, Neves LB, Luciano RM, Dahroug MAA, Amendoeira MRR, 2011. Seroepidemiology of toxoplasmosis in goats and sheep from three counties of Rio de Janeiro state, Brazil. Pesq Vet Bras 31:569-74.

Meneguzzi VC, Santos CB, Pinto IS, Feitoza LR, Feitoza HN, Falqueto A, 2009. Use of geoprocessing to define malaria risk areas and evaluation of the vectorial importance of anopheline mosquitoes (Diptera: Culicidae) in Espírito Santo Brazil. Mem Inst Oswaldo Cruz 104:570-5.

Millar PR, Alves FMX, Teixeira VQ, Vicente RT, Menezes EM, Sobreiro LG, Pereira VLA, Amendoeira MRR, 2012. Occurrence of infection with Toxoplasma gondii and factors associated with transmission in broiler chickens and laying hens in different raising systems. Pesq Vet Bras 32:231-6.

Moura L, Bahia-Oliveira LM, Wada MY, Jones JL, Tuboi SH, Carmo EH, Ramalho WM, Camargo NJ, Trevisan R, Graça RM, da Silva AJ, 
Moura I, Dubey JP, 2006. Waterborne toxoplasmosis, Brazil, from field to gene. Emerg Infect Dis 12:326-9.

Oliveira LN, Costa-Junior LM, de Melo CF, Ramos Silva JC, Bevilaqua CM, Azevedo SS, Muradian V, Araújo DA, Dubey JP, Gennari SM, 2009. Toxoplasma gondii isolates from free-range chickens from the northeast region of Brazil. J Parasitol 95:235-7.

Ortega-Pacheco A, Acosta Viana KY, Guzmán-Marín E, Segura-Correa JC, Alvarez-Fleites M, Jiménez-Coello M, 2013. Prevalence and risk factors of Toxoplasma gondii in fattening pigs farm from Yucatan, Mexico. Biomed Res Int 2013:231497.

Patton S, Rabinowitz A, Randolph S, Johnson SS, 1986. A coprological survey of parasites of wild neotropical felidae. J Parasitol 72:51720.
Rocha CFD, Bergallo HG, Pombal Jr. JP, Geise L, Van Sluys M, Fernandes R, Caramaschi U, 2004. Fauna of amphibians, reptiles, and mammals of the State of Rio de Janeiro, Southeastern Brazil. Publ Avul Mus Nac 104:3-23.

Silva AVM, Magalhães MAFM, Brazil RP, Carreira JCA, 2011. Ecological study and risk mapping of leishmaniasis in an endemic area of Brazil based on a geographical information systems approach. Geospat Health 6:33-40.

Silva DS, Bahia-Oliveira LMG, Shen SK, Kwok OCH, Lehman T, Dubey JP, 2003. Prevalence of Toxoplasma gondii in chickens from an area in southern Brazil highly endemic to humans. J Parasitol 89:394-6.

UNDP, 2013. Brazilian atlas of human development 2013. Available from: http://www.ibge.gov.br/estadosat/ 